\title{
Faith, Crisis, Coping, and Meaning Making After Katrina: A Qualitative, Cross-Cohort Examination
}

\author{
Loren D. Marks \\ Brigham Young University - Provo, loren_marks@byu.edu \\ Katie E. Cherry \\ Louisiana State University at Baton Rouge \\ Jennifer L. Silva \\ Louisiana State University at Baton Rouge
}

Follow this and additional works at: https://scholarsarchive.byu.edu/facpub

Part of the Other Social and Behavioral Sciences Commons

\section{Original Publication Citation}

Marks, L. D., Cherry, K., \& *Silva, J. (2009). Faith, crisis, coping, and meaning making after Katrina: A qualitative, cross-cohort examination. In K. Cherry (ed.), Lifespan Perspectives on Natural Disasters: Coping with Katrina, Rita and other Storms (pp. 195-215). New York: Springer.

\section{BYU ScholarsArchive Citation}

Marks, Loren D.; Cherry, Katie E.; and Silva, Jennifer L., "Faith, Crisis, Coping, and Meaning Making After Katrina: A Qualitative, Cross-Cohort Examination" (2009). Faculty Publications. 4907.

https://scholarsarchive.byu.edu/facpub/4907

This Book Chapter is brought to you for free and open access by BYU ScholarsArchive. It has been accepted for inclusion in Faculty Publications by an authorized administrator of BYU ScholarsArchive. For more information, please contact ellen_amatangelo@byu.edu. 


\title{
Chapter 10
}

\section{Faith, Crisis, Coping, and Meaning Making After Katrina: A Qualitative, Cross-Cohort Examination}

\author{
Loren D. Marks, Katie E. Cherry, and Jennifer L. Silva
}

\begin{abstract}
Very few studies in the disaster literature include elderly adults, whose life experiences, perceptions, and spiritual needs in the post-disaster period may markedly differ in comparison to younger cohorts. In this chapter, we address the topic of how young, middle age, older, and oldest-old adults coped with and made meaning of Hurricanes Katrina and Rita during the storms and their aftermath. The individuals who provided the qualitative interviews upon which this chapter is based were enrolled in the Louisiana Healthy Aging Study (LHAS), a multidisciplinary study of the determinants of longevity and healthy aging (see Cherry, Silva, \& Galea, Chapter 9 of this volume). We begin this chapter by presenting three central themes to contextualize our findings. These themes include (1) crisis, in the sense of a significant, developmental turning point (cf. Erikson E.H., 1998); (2) coping, a behavioral response to stressful events; and (3) meaning making, which pertains to an individual's unique interpretation of an event and attributions for why it happened. We describe the sample, interview procedures, coding process, and emergent themes arising from the qualitative interviews. Implications for adjustment, acceptance, and personal growth in the post-disaster period are considered.
\end{abstract}

\section{Introduction}

Hurricanes Katrina and Rita have brought unparalleled destruction and immeasurable losses to the people of South Louisiana and the Gulf Coast region. Both the media and the popular press have riveted our attention to the catastrophic losses and suffering of hundreds of thousands of people in the storm-ravaged Gulf Coast. It is important to realize that the influence of these treacherous storms has been felt widely by countless numbers of people, including those who live outside of the severely storm-damaged areas. In this chapter, we focus on the experience of a

\footnotetext{
L.D. Marks $(\bowtie)$

Division of Family, Child and Consumer Sciences; School of Human Ecology; and Life Course and Aging Center, Louisiana State University, Baton Rouge, LA 70803-5501, USA

e-mail: lorenm@1su.edu
} 
sample of adults in South Louisiana who ranged in age from early 20s to 90 years and older. These persons were enrolled in the Louisiana Healthy Aging Study (LHAS), a multidisciplinary study of the determinants of longevity and healthy aging (see Cherry et al., Chapter 9). They reside in greater Baton Rouge, outside of the areas severely impacted by Katrina and Rita. Few evacuated at the time of the storms, yet nearly all had family and close friends who lived in the more heavily storm-damaged areas. Many LHAS participants sheltered displaced family and friends in their homes for days and weeks on end during the post-impact period (see Cherry, Galea, \& Silva, 2008 for discussion).

Our central mission in this chapter is to allow LHAS participants' voices to be heard. Emergent themes arising from their qualitative interviews are rich with local and historical color, as well as having noteworthy implications for successful aging. We begin by presenting an overview of the three central issues of this chapter, crisis, coping, and meaning making, to contextualize our later discussion of the findings. In light of our objective to focus on LHAS participant voices, a brief overview of core concepts that emerged in the research project will supplant an extended traditional review of literature. In the next section, we describe our qualitative research methods. All of our participants were affected by Hurricanes Katrina and/or Rita $(\mathrm{HK} / \mathrm{R})$ but were kind enough to share their stories and thoughts with us. The breadth of experience in the LHAS study sample is astonishing, with stories that ranged from early recollections of the outbreak of the flu epidemic of 1918 (see also Allen \& Wayne, Chapter 8) and unnamed storms of the late teens and early 1920s, to the Flood of 1927, to more recent storms, including Hurricanes Audrey in 1957, Betsy in 1965, Camille in 1969, and Andrew in 1992 (Cherry, 2006). In the last section, we present three emergent themes which constitute the major findings of this portion of the study. This chapter is based solely on the qualitative interviews conducted shortly after the hurricanes struck in late August and September of 2005. We conclude by considering the emergent themes identified here in relation to psychological well-being and personal growth in the post-disaster period.

\section{Three Central Issues in Overview}

\section{Crisis}

In his psychological theory, Erik Erikson (1998) introduces eight stages of development, each of which is characterized by a crisis or central struggle (e.g., the struggle between identity and identity confusion during adolescence). Joan Erikson (1998) added a ninth stage, gerotranscendence, to address the growing 90+ years old population that both she and her late husband lived long enough to join. This ninth stage of $90+$ years is especially relevant to our chapter because this population is represented in our study by Cohort 4 (as we will discuss later). Although all of the Eriksonian stages involve a crisis, for Erikson crisis is not synonymous with tragedy. Instead, a crisis is a developmental point where an individual is confronted by a specific challenge. If one is successful in overcoming the crisis, the 
individual progresses to the next stage. If the crisis is not resolved, development stagnates. However, whether progression or stagnation occurs, it is not possible to simply return to pre-crisis life. Crises are not singular events, but challenges that recur in each of the nine stages across the life span.

Hurricanes Katrina and Rita (HK/R) presented South Louisiana with natural disasters unparalleled in her modern history, but the hurricanes did more than this. For many of Louisiana's sons and daughters, the hurricanes served as crises in the Eriksonian sense. For the participants who were interviewed and hundreds of thousands like them, pre-HK/R life is irretrievably gone. Perhaps no extant research captures this reality as richly, or as bleakly, as Pulitzer-nominated journalist Chris Rose's (2007) documentary volume 1 Dead in attic. In his book, Rose captures New Orleans in the Katrina aftermath with a poignant depth and feel. An overriding theme is that of a city (and individuals) in crisis. Consistent with Erik Erikson's work, Rose portrays the duality of crisis in a way that captures hope and despair-generativity and stagnation.

Pauline Boss (2002), arguably the nation's leading scholar of family stress, has added her reminder that crisis is not inherently and absolutely negative, and even argues that crisis presents opportunity. Similarly, Webster's New World Dictionary (1991, 3rd ed.) defines crisis as "the turning point...for better or worse" (p. 328). Finally, the late psychiatrist Viktor Frankl (1984) has extended this line of thinking even further by arguing that meaning is often found in the struggle. Frankl's argument is captured in his statement that

What man actually needs is not a tensionless state but rather the striving and struggling for a worthwhile goal, a freely chosen task.... If architects want to strengthen a decrepit arch, they increase the load which is laid upon it, for thereby the parts are joined more firmly together (pp. 127-128, emphasis in original).

The above perspectives on crisis are relatively positive and optimistic; certainly crisis can be viewed in more malignant ways. However, this brief overview is a generally appropriate fit for the participants in our study. We next turn to a discussion of coping, a process that may lessen the challenges and assist in crisis resolution with potential for positive growth and personal development.

\section{Coping}

Coping is broad term that comprises a wide range of variables (e.g., Menaghan, 1983; Nesteruk \& Garrison, 2005). It is generally defined as the process by which resources are used to respond to stressor events (Garrison, Malia, \& Molgaard, 1991; see also Silva, Marks, \& Cherry, Chapter 11).

Coping, like crisis, is inherently dualistic. Crisis typically holds a negative connotation but involves positive potential as well (Boss, 2002). Similarly, coping can be negative and/or positive. While coping frequently carries a positive and resilient connotation, there are negative or "red flag" approaches to coping as well, such 
as coping by turning to alcohol and drug abuse (Marks, Swanson, Nesteruk, \& Hopkins-Williams, 2006; Pargament, 1997) or by being primarily reactive instead of proactive (Garrison et al., 1991). In this chapter, however, we will focus on positive coping.

To offer a historical glance, nearly 60 years ago Reuben Hill (1949) developed the "roller-coaster profile of adjustment to crisis" in the wake of post-World War II family dissolution (p. 14; see also Koos, 1946). In this early view of coping, families go through four stages: "crisis, disorganization, recovery, and reorganization" (Ingoldsby, Smith, \& Miller, 2004, p. 138). Hill (1949) also developed the ABC-X model of family stress wherein $A$ represents a stressor event, $B$ represents available family resources and strengths, and $C$ represents the family's definition of the situation. $X$ represents the resulting stress and crisis; in other words, the outcome of how the family responds to and defines the initial stressor. Although the ABC-X model has received several modifications by other scholars, these basic concepts still serve as the foundation for much of the current research on family stress and coping (Ingoldsby et al., 2004).

In the present study, Hurricanes Katrina and Rita serve as the initial stressors ("A") that provide a rich (although tragic) context for examining key resources and strengths ("B"), and individual and family definitions ("C") that exacerbated or minimized personal and familial crises ("X"). In this chapter, our findings will focus particularly on key coping resources and approaches. Having briefly overviewed coping, we turn to the third central concept of meaning making.

\section{Meaning Making}

Psychiatry's most influential work on meaning making is arguably Viktor Frankl's (1984) Man's Search for Meaning. The body of this work is largely comprised of a section entitled "Experiences in a Concentration Camp," in which Frankl describes his accompanying struggle and search for meaning. Near the conclusion of his autobiographical notes, Frankl states, "Everything can be taken from a man but one thing: the last of human freedoms - to choose one's attitude in any given set of circumstances, to choose one's own way" (p. 104). While it is certainly not our intent to compare the thousands of people in the Gulf Coast region who survived Katrina to those from Auschwitz or Dachau, the profound physical losses suffered by many in South Louisiana and Mississippi remind us that much (if not "everything") can be taken from a person in the tangible sense. In spite of heartbreaking losses such as these, Nietzsche has argued that "he who has a why to live for can bear with almost any how" (cf. Frankl, 1984, p. 97). The hurricane survivors [many dislike being referred to as "victims," (Rose, 2007)] were forced to answer some pressing why and how questions, not just intellectually but pragmatically. The following statement from H. E. Fosdick seems to capture the struggle faced by our participants:

We must believe that there is a purpose running through the stern, forbidding process. What men have needed most of all in suffering, is not to know the explanation, but to know that 
there is an explanation. ... [We need] confidence that human tragedy is not the meaningless sport of physical forces, making our life what Voltaire called it, 'a bad joke' (Fosdick, 1918, p. 20 , emphasis added)

As we will illustrate later, this struggle for meaning, explanation, and purpose was salient and pervasive among our participants. We now turn to a discussion of the qualitative method we used in our efforts to better understand crisis, coping, and meaning making among those participants in our sample.

\section{Method}

\section{Sample and Interview Procedures}

The study sample consisted of 72 predominantly Caucasian adults who were enrolled in the Louisiana Healthy Aging Study (LHAS) with four age groups: younger adults $(M=37.7$ years, $S D=5.3$ years, 2 males, 11 females $)$, middleaged adults $(M=54.0$ years, $S D=5.7$ years, 10 males, 7 females $)$, older $(M=$ 74.3 years, $S D=7.0$ years, 8 males, 11 females $)$, and oldest-old adults $(M=91.9$ years, $S D=1.2$ years, 10 males, 13 females). All were free of neurologic impairment due to stroke or adult dementia. Participants were tested individually in their home or in the laboratory at Louisiana State University (LSU) across two sessions that lasted approximately an hour to $1 \mathrm{~h}$ and $30 \mathrm{~min}$ each. Younger participants were tested in a single session, if desired. On the first day, informed consent was obtained and the quantitative measures were administered (see Cherry et al., Chapter 9, for a description). Next, participants were given a list of seven open-ended questions to read during a break period for those tested in a single session and to take home and consider for those tested across two sessions. On the second day (or second half of a single session), participants answered the questions and their responses were tape recorded. Audiotapes were transcribed for the purpose of qualitative coding (described next). In this chapter, we focus on their responses to the religious coping question, as follows: "In times of trouble, people often turn to their religion and spiritual beliefs to help them cope with life stresses. Have your religious beliefs and practices helped you cope with Hurricanes Katrina and Rita. If so, in what way? Please tell us about how your beliefs helped you cope when the storms first hit and also cope with the challenging times after the hurricanes." Following the open-ended questions, remaining quantitative measures (not addressed in this chapter) were administered and debriefing followed.

\section{Analysis and Coding}

The qualitative interview data were analyzed in a manner consistent with grounded theory methodology (Strauss \& Corbin, 1998). Open coding (identifying themes and concepts in the interview data) was performed independently by five members 
of our research team on an interview-by-interview basis. We met once a week for several months to discuss, compare, and contrast our independent open coding from the previous week on a line-by-line, page-by-page basis, with each member alternatively "leading out" by discussing her/his personal open coding of a given page. Following presentation of one's independent coding of a given page, the other four members would discuss similarities and differences from their coding. Researchers also did content analyses of their open coding for each interview, similar to Miles and Huberman's (1994) "data accounting sheet" (p. 80). At the conclusion of the coding, researchers' content analyses for each interview were collected and compared, offering five "at-a-glance" perspectives of the concepts and themes expressed in each of the interviews (cf. Marks, Nesteruk, Swanson, Garrison, \& Davis, 2005). Next, the central themes were identified based on two factors: prevalence (within and across interviews) and salience.

To ensure that each of these themes were verifiable and clearly supported by the data, each member was assigned one theme which they were asked to confirm. Team members then revisited all of the interviews and copied and pasted all data that had been directly identified with the theme. The result was that each theme had several pages of supporting data-consistent with Patton's (2002) suggestion of creating a data "audit trail" (p. 93).

In a final exercise to increase rigor, we then worked through a triple-check reliability assurance process. In overview, this process included the following steps:

1. Each team member composed a file that included all of the excerpts coded in connection with that code/theme.

2. Each team member was assigned to review another member's file as a double check. She looked for any data segments that related to the theme that were overlooked or missed-as well as looking for excerpts that were "a stretch."

3. A third team member then repeated the check procedure, so that each of the themes (and the supporting data) were triple checked to ensure inter-rater reliability and to minimize idiosyncratic bias.

Having discussed our attempts to be methodologically systematic and rigorous, we now turn to a note on reflexivity.

\section{Reflexivity}

Reflexivity involves discussing how personal experience and biases might color one's collection, analysis, and reporting of the data. Accordingly, we note that living through Hurricanes Katrina and Rita in Baton Rouge (where all of the authors resided) was somewhat surreal (see Cherry, Allen, \& Galea, 2009, for discussion). At LSU, the Pete Maravich Assembly Center (home to basketball games and commencement exercises) became a hospital/triage center run largely through the volunteer efforts of LSU students (Bacher, Devlin, Calongne, Duplechain, \& Pertuit, 
2005). By some estimates, Baton Rouge's population doubled almost overnight. In addition to the destruction and several days of power outage, there was scarcity. It is difficult to capture the eerie feeling of seeing nothing but bare shelves on the bread aisle at the grocery store, or the sinking realization that there is no more gasoline at your corner pump - or in your vehicle. Many of us in Baton Rouge had friends, family, or former strangers from flooded areas living under our roofs. We, however, were only grazed by comparison to those from New Orleans, Slidell, and the other decimated areas. Here in Baton Rouge, we had no power and precious little gas or food...but we had our families, our homes, our jobs, our belongings, and our photo albums - those precious books that research indicates are the one tangible item most of us would grab first in the event of home destruction (Gilbert, 2006). For us to pretend that we understand what those from the flooded areas experienced would be dishonest. Yet, we do have a desire to report what our participants told us to the best of our ability. Our hope is that our HK/R experiences have softened us enough to be subjective in a sensitive and positive way-while still maintaining sufficient objectivity.

\section{Findings}

In the paragraphs that follow, we discuss three of the major themes that emerged from our team-based analysis of the qualitative interviews. The themes include (1) Crisis: Tragedy, Opportunity, or Simply "Part of Life"?; (2) Approaches to Coping: Comparison, Gratitude, Optimism, and Personal Strength; and (3) Meaning Making: "God is in Control...Right?" In connection with each of these three major themes, we provide illustrative and supportive excerpts from the participants' interviews. Consistent with our desire to allow LHAS participants' voices to be heard, we have tried to keep our explanations and interpretations at a functional but minimal level, in order to allow the reader to construct his/her own meanings. The first theme we will highlight is that of crisis — which Erik Erikson (1998), Boss (2002), and Webster (1991) all define as a developmental turning point.

\section{Theme 1-Crisis: Tragedy, Opportunity, or Simply "Part of Life"?}

The definitions of, and the responses to, Katrina and Rita as crises were diversenot only across the state, but in our sample. Many viewed the time of crisis as a time for re-evaluation. A 42-year-old man reported:

HKR 3: A lot of things are [not that important]...[the hurricane gets you] re-evaluating where you are in your life, what you're doing, what is important to you.... I am Christian. . . but I would think that even the atheist, after Hurricane Katrina, would have to sit down and. . . not suddenly believe in God, but they would have to sit back and re-evaluate where they are in life and realize how precious life is. 
An African American woman (age 39) similarly discussed her re-evaluated and altered perspective:

HKR 15: [Going through Katrina and the aftermath] has been a humbling experience and it has changed my life in a way that I really can't even explain. $[\mathrm{H}]$ elping people, that helped me to cope. [I] couldn't remember any problems that I had prior to Katrina, because I took on so much other stuff, helping other people...[it] drowned out what I was going through and God fixed [those other problems].

The participants' reflections regarding re-evaluation often included notes on personal religious revival, as the following four examples illustrate:

HKR 4, 35 years: I think [an] event like this it makes you. . if you are religious person and spiritual, then I think it brings you back [to God]. I think that's why things [like Katrina] happen...not that God wants everybody to be devastated...but... I think that different things happen to make people realize what is important, to come back and find Him and know that He is going to be there for you.... I think it just reminds you how important it is to have [God] in your life.... You kind of get relaxed about looking to God... and when something like this happens... right there in your face [it brings you back].

HKR 7, 38 years: I think [Katrina] affected me and our family in wanting to know more about the Lord and his words.... To actually go back to the [Bible] and read. . . that helped us.... I realized that in times of trouble, [we] go back to that.

HKR 112, 54 years: Hurricane[s] Rita and Katrina. . .made a couple people. . .go to church to thank the good Lord that they [are] still here [and breathing].

HKR 105, 48 years: Right after [Katrina and Rita] hit, I think that people [did] turn to their spiritual beliefs and (go back to God).

Although little previous research has examined religion and spirituality in the aftermath of natural disasters, the above statements resonate with previous research conducted on the East Coast in the months following the 9/11 attacks on the Twin Towers and the Pentagon (Marks, 2002). In that study, a Jewish mother reflected:

I mean, it was just an automatic thing to go to synagogue and to look at death from a Jewish perspective.... I think that after September 11, with the [terrorist] attack, we instinctively went to synagogue the next Friday night, and it was packed. I think that's just how we cope (p. 47).

As we see above, traumatic events like 9/11, Katrina, and Rita can stimulate actions including re-evaluation, revival, and a search for deeper purpose-at least for some. Indeed, the interviews of several of our participants called to mind the quip that some of us spend our lives "climbing the ladder of success only to discover [that the ladder is] leaning against the wrong wall" (Covey, 2004, p. 98).

The above excerpts, however, represent only a portion of the story behind the first theme of crisis. Our study covered four major cohorts (20-44 years, 45-64 years, 65-89 years, and 90 years and over). For all in this study, hurricane damage and losses were relatively minimal compared to other areas of the state as reported elsewhere (see Cherry, Galea, et al., 2009). Overall, the four cohorts were largely comparable in terms of storm exposure and impact. It is important to note, however, that all of the above excerpts portraying HKR as a crisis are from the two younger cohorts. In the Eriksonian sense outlined at the beginning of this theme, 
the two younger (under age 65) cohorts generally viewed the hurricanes as lifealtering crises and discussed the disasters and their aftermath in relatively dramatic terms. By comparison, many of the individuals in the older two cohorts were almost sanguine-especially by comparison with the younger cohorts. Consider the following six examples, all of which are drawn from the two older (65 years and up) cohorts:

HKR 212, 65 years: [I try to] just to keep on keeping on. That is all you can do.

HKR 301, 91 years: I just don't have any terrified feelings.... I really don't (worry).... Like I say, one of these days [it'll be my time]. . . but I'm not going to go. . .until it comes.

HKR 308, 91 years: You just do what you can to.... It'll settle down. We'll live through it and wait for the next one. [You know], water seeks its level, and that's what's going to happen to everybody. We'll manage.

HKR 315, 93 years: I think that I have a satisfactory relation with God and [so] I am comfortable... whatever [the] outcome.

HKR 316, 91 years: I think things will be alright.

HKR 320, 91 years: All my life, I've been well taken care of, so I'm. . . just thankful and feel blessed. ... I [have] been taken care of all these ninety-one years and I just [feel fortunate].

The above responses are not only qualitatively different in terms of the level of (or lack of) dramatic intensity they convey, the responses are also brief and direct, almost laconic. More detailed comments from the two senior cohorts included the following:

HKR 308, 91 years: I'm older. I['ve] had a lot of experience. I've been through stresses so much, I'm used to it. I'm hardened by it. I can take it.... We'll live through it and wait for the next one. ...Time heals...

HKR 301, 91 years: When you look at something and it looks pretty dark. . .there's got to be a light behind it somewhere.... Maybe you kind of give in to [darkness] for a while, but you know that it's going to change. I just think, "I'm going to get out of it". . . and here I am. HKR 218, 66 years: I just. . . have a trust that things will work out one way or the other, and whatever works out, there's a final lesson, a blessing, or something to be gained [from] it.

Some participants, like the latter (HKR 218), used the spiritual terms "blessing" and "blessed," even during the hurricanes' aftermath. Others tended to be more specific in their religious references, choosing to discuss God and their sense of relationship with the divine. The following two quotations are representative:

HKR 219, 86 years: I am not saying this for anyone to think that I am not a sinner because I am a sinner. We all know that that we are sinners, but there is always hope, there is always a new day, there is always a call in God.

HKR 207, 89 years: I don't dwell on [Katrina] because it's something that I cannot do anything about, other than feeling like the Lord will give me the protection I need. . . . [Often in life, it] look[s] like everything goes wrong, but right behind that, everything come[s] out alright. [I feel that eventually] everything's going to be alright.

In some instances, a participant's sense of a personal relationship with God was captured in portions of conversations with the divine that he or she shared with the interviewer. HKR 306, age 91, was one such individual. She explained:

I said, "Lord, You've always kept a roof over my head, given me food to eat, and taken care of me. And I know you will [get me] through this in some way." 
As our qualitative research team coded, analyzed, and discussed the interviews, we compared and contrasted key findings, themes, and tendencies across cohorts. Those members of the research team who were less familiar with gerontology and with cross-cohort studies of later adulthood were struck by some of the differences between the age-graded emotional and the psychological differences manifested in the interviews. As discussed previously, our coding procedures were highly democratic, with every member having an opportunity to weigh in on each page of interview data. Predictably, there were occasional points of difference. However, points of unanimous consent included the team's conclusions that (a) In many ways, Cohorts 1 and 2 resembled each other, while Cohorts 3 and 4 also resembled each other; and (b) In many ways, Cohorts 1 and 2 were distinctly different from Cohorts 3 and 4, in that the two younger cohorts ( 1 and 2 ) seemed to view and portray the hurricanes and their aftermath as crises, while the senior cohorts seemed to view them as additional experiences.

As mentioned earlier in the paper, if crises are turning points, then coping is the process through which we determine whether our subsequent trajectory is downward or upward. It is to this process of coping that we turn in theme 2.

\section{Theme 2-Approaches to Coping: Comparison, Gratitude, Optimism, and Personal Strength}

During our analyses of our participants' interviews, references to coping were abundantly coded. Nearly all of our participants discussed coping at some level. Additional coding of the data that related specifically to coping identified at least four major approaches to coping. These are not pure types; indeed, they often overlapped. Nevertheless, these approaches to coping were distinguishable and salient. These approaches included (a) beneficial comparison, (b) gratitude, (c) optimism, and (d) personal strength. Each approach to coping is addressed and illustrated next.

Sub-theme 1: Beneficial comparison as a coping strategy. Many of our participants suffered personal, familial, and property-related losses during Katrina and Rita that are reported elsewhere (Cherry, Galea, et al., 2009). Even so, most chose not to delineate or bemoan their losses during their interviews. It was quite common, however, for participants to comment on others whose losses were far more severe-even if these people were only passing or casual acquaintances or "people on TV." These comparative references recurred frequently enough to establish this tendency as an important and often valuable coping approach. One participant mentioned "helping other people. .. [and seeing their problems] drowned out what I was going through" (see also Silva et al., Chapter 11). Although no interview question asked them to do so, many participants explicitly compared their own post-HKR circumstances favorably with others, as the following three statements reflect:

HKR 104, 60 years: I'm just fortunate I don't have as much [repair] work to do as some of the people. 
HKR 302, 93 years: Well, when the storm hit, ... [I was] thanking God that we weren't hit [as bad as some people].

HKR 116, 52 years: [I quit feeling so bad for myself] once I realized that there would be people that would never find their family members, you know. When you go to those [relief] sites and see how many people were looking for people, and how many of those people were looking for [their family members]. .. so many people that cannot afford [much of anything]... [it makes you slower to complain].

One participant (HKR 305), age 93, similarly commented:

[W]hen I think of those people who had lost everything, I realized how blessed I am... . [I also think of poor] people in other parts of the world...[and] the people living right here in our own country who have been victims of all these tornados, up in Tennessee.... I feel like I [have] be[en] so blessed to be able to have what I have and be as safe as I am.

Another older participant (HKR 312), age 91, said:

[I] stop and think that so many don't have [a thing in the world]. [Now], I ain't got [hardly] nothing, but so many people don't have what I got. . . I [say to myself], "Well, I got those old scraps. I think I'll wear them." If anybody don't like them, they don't have to come see me.

A vivid and concluding example of the power of coping through beneficial comparison was offered by a participant (HKR 7), age 38, who reported that a New Orleans woman who had lost her home and everything in it visited the church where our participant attended shortly after Katrina hit. The visiting woman asked permission to sing a solo hymn of praise for the congregation, a gesture that profoundly affected our participant. She (HKR 7) reflected:

Still to this day, she just made me feel so [much]. ... I was [thinking], "We just lost [electrical] power [for a few days and had relatively minor damage], you know. And you are here and you lost everything and you are singing praises to the Lord."

As we see from the above statements, favorable comparison of one's own circumstances with those of others in more dire straits was reported as a helpful and sometimes even transformative approach to coping used by many participants, whether they were consciously aware of this coping strategy or not. A second approach to coping is discussed next.

Sub-theme 2: Gratitude in the face of loss. The field of positive psychology has grown in recent years and focuses on the pursuit of optimal human functioning by developing specific inner strengths, such as optimism, courage, hope, and honesty (Seligman, 2004; Seligman \& Csikszentmihalyi, 2000). It is believed that individuals can enjoy a fulfilling life and thrive if these internal characteristics are fostered. In this positive psychology literature, there is little extant research which examines the mental and emotional states of individuals following catastrophic events. Furthermore, there have been even fewer studies in contextual settings that compare with the real-world laboratory of post-HKR South Louisiana. As a result of the novel context, we knew little about what to expect in terms of the participants' psychological states. As a research team, we were struck by how frequently the participants' responses exuded health, optimism, and a generally positive approach to coping. Some of our participants even expressed gratitude and a conviction that they would avoid taking life for granted, as the following three excerpts illustrate: 
HKR 9, 42 years: [I was reminded] that we shouldn't take for granted what we have. [...] I realize how good we have it and I'm very grateful, thankful. . . and I thank Him [God] for that on a daily basis. I don't take for granted that I've got a good life...

HKR 305, 93 years: I was blessed, and I have been blessed through all these ninety, almost ninety-four years. [I] was not unfortunate in having to cope with the hurricanes personally. You know, [by comparison to some] I didn't have... .problem[s] at all. I was blessed.

HKR 306, 91 years: [For now, I am grateful to be staying with family]. I enjoy being here. I enjoy [and] love my family and I like to be with them. ... [Unlike many, I made it through this but] I know that when I [die], I'll go to a better place.

In terms of positive psychology, one participant (HKR 9) framed Katrina as a reminder that she "shouldn't take for granted" what she has, and went on to call herself "very grateful." HKR 305 referred to herself as "blessed" and "not unfortunate"- but it is probable that these are euphemistic terms for losing less than everything. Indeed, the latter participant (HKR 306) was without her home, perhaps permanently, but she still focused on the joy she felt in being with her family. Simple phrases of gratitude such as these are not uncommon to hear in daily life from the more positive persons around us-but against an oppressively dark backdrop of Katrina-induced loss, statements like "I enjoy [and] love my family and I like to be with them" are made striking by effect of contrast.

Sub-theme 3: Optimism as a coping resource. Many participants did not go so far as to express gratitude but still exuded an optimism-an optimism that in spite of the natural disasters they would cope well and come out strong, maybe even stronger (see Garrison \& Sasser, Chapter 6, for a related discussion). Some individuals invoked timeworn but optimistic phrases, as reflected in the following three comments:

HKR 9, 42 years: I'm trying to look at my glass as half-full not half-empty. I'm trying to look on the optimistic side here.

HKR 105, 48 years: A lot of times there is a silver cloud, a silver lining behind every dark cloud, and I think that people's faith was tested in a lot of ways [during Katrina]...but I think that people, including myself, [are] generally optimistic that things [are] going to get better. . that there are better times ahead.

HKR 305, 93 years: I do think that every cloud does have a silver lining, and that all of these things when they happen to us, there is a reason.

Other participants like HKR 15, age 39, drew analogies. She stated:

I just know that in spite of what I go through or may face even in future life, it's just for a season, and we do know that storms come in seasons, you know, it's hurricane season so storms come in your nature life as well as your spiritual life.

Others, like the following two participants, offered their personal philosophies:

HKR 105, 48 years: I. . .just have an optimism and faith that things will get better and that there is maybe even a reason, I hate to say a reason, [that Katrina] happened. But we can learn and benefit from even something so awful as this, and look to the positive end of it. HKR 207, 89 years: [Sometimes it] look[s] like everything goes wrong, but right behind that, everything come[s] out all right. [...]Everything's going to be all right.

Having addressed the third psychological coping resource of optimism, we now turn to a final related sub-theme. 
Sub-theme 4: Personal psychological strength. Many participants' comments, like those above, conveyed an optimism that "things will get better." A handful of others did not explicitly express optimism (much less gratitude), but nevertheless offered comments that addressed more internal, personal psychological qualities or characteristics that seemed to serve as coping resources for them. The following three statements are representative of this group:

HKR 108, 47 years: It's not that I am naive or that I am just that I am [too] ignorant to know that bad things happen to good people. It's just, I have never been a depressed, stressed out person...

HKR 202, 70 years: Being the [strong] type [of] personality that I am, I had no problem.

HKR 315, 93 years: Under the circumstances, ...I just accepted things the way they were. ...I think things will be alright. I just accept them the way they are. That [part of my personality] didn't change. I still do the same thing, [I accept things and move on].

It might be said that in terms of coping, we had a grateful group, an optimistic group, and an accepting but strong group. Some individuals, however, had a flair of their own. One participant (HKR 104), age 60, a colorful character with some New Orleans swagger, offered one of the most memorable lines of our project:

Like I [have] always said, "Life's a bitch and it has puppies." So whatever He (God) throws you... [it may be tough now, but something good will come of it].

To summarize our overall findings on approaches to coping, there were several facilitative processes exemplified by our participants. Some used a beneficial comparison approach that involved focusing on those who were relatively less fortunate, thereby curbing tendencies toward self-pity. Others, in spite of tangible and intangible losses, focused on what they still had and expressed gratitude for these things. For others, optimism seemed key. Finally, some participants focused on personal psychological strengths as a resource that helped them cope. Taken as a whole, these coping approaches offered a varied array of positive psychological approaches that helped our participants as they coped with the worst natural disasters in their state's history. Having discussed two of the three central themes of this paper, we now turn to the final theme of meaning making.

\section{Theme 3-Meaning Making: “God is in Control. . .Right?”}

In this theme we seek to convey how participants struggled to find meaning in the wake of catastrophic carnage and loss. One approach to "explain" and make meaning out of Hurricane Katrina was to view it as the result of divine wrath over the sexual activities in New Orleans' French Quarter. A local reverend, Bill Shanks, represented this view in a widely distributed Internet message, a portion of which read:

New Orleans now is Mardi Gras free. New Orleans now is free of Southern Decadence and the sodomites, the witchcraft workers, false religion-it's free of all those things now. God simply, I believe, in His mercy, purged all of that stuff out of there... (cf. Rose, 2007, p. 29). 
Although none of our participants explicitly endorsed this view, the view was prevalent enough in local conversations to enter into our participants' consciousness. Several spontaneously drew attention to these views and then offered their rebuttals. Some participants, like the following three, simply rejected the notion that Katrina was a divine wake-up call or punishment.

HKR 220, 77 years: I heard a comment made that the Lord [sent] the hurricanes [to tell us] we have to change our ways and things like that. [Some say that] He is giving us these things because we're not living the way we should. [...] That's really not true.

HKR 111, 53 years: I do not believe that this was. . .a sign of God, or a punishment from God, but I do believe that God can help us cope and can help give us strength.... [What did Katrina mean?] I think it was a hurricane (Laughs). That is all I think it was. [...] God is not a hateful, vengeful God that is striking us like this because of too many gays in New Orleans...

HKR 202, 70 years: I think that those that feel God is punishing [us in] some way [are] ridiculous. I don't think it's the act of God or punishment. It's nature, actually.

Other participants also offered rejections of the "Katrina as punishment" concept but continued further to point out inconsistencies and contradictions they saw in this view. The following two insights were among the more cogent arguments presented by participants:

HKR 2, 32 years: I didn't see it as God coming after us.... God didn't do this to us. . .to punish us. I heard that so much, that God just took out New Orleans because it was such a sinful place. No... Mother Nature took New Orleans out-and it would have taken out anything that was there, whether it was New Orleans or a little podunk town.... You know, [Katrina] took out Slidell too and that's a suburban area.

HKR 210, 67 years: I heard somebody say that because New Orleans was a sin city, God cause[d] it (Katrina). I don't believe God causes things. I don't believe He causes cancer in children. I don't believe He causes these [hurricanes]. For one thing, Bourbon Street [in the heart of the French Quarter] was not really damaged and some churches were damaged. So, I mean I [don't think] that God would save... the "bad people" and ruin the churches. I mean God didn't have anything to do with it.

Both of the above rejections resonate with those of New Orleans' social chronicler Chris Rose (2007) who remarked:

[T]ry telling some poor sap...who has never heard of Southern Decadence and who goes to Bible study every Wednesday night that he lost his house and his job and [that] his grandmother died in a flooded nursing home because God was angry at a bunch of bearded guys in dresses over on Dumaine Street. [...] How come Plaquemines, St. Bernard, the East, and Lakeview are gone but the French Quarter is still standing? (p. 29).

From a psychological standpoint, these participants were engaged in a process that might be called negating. Although most of the aforementioned persons do not attempt to explain or verbalize what Hurricane Katrina meant, these participants were passionate in expressing what the hurricane did not mean to them-namely, Katrina did not mean that God wanted to destroy New Orleans.

Erik Erikson's (1998) theory of development includes a focus on the development of psychological identity during adolescence. A primary task in identity development involves "the selective affirmation and repudiation of an individual's [early] 
identifications" (p. 72, emphasis added). In other words, adolescents make key decisions about who they are by rejecting or repudiating who they are not. Erik Erikson posits that "later an existential identity [forms] which. . .transcends the psychological one" (p. 73). In this quest, "defiance" and "negative identity" are again integrals, just as they are during early identity formation. In short, as we struggle to find and create existential meaning and identity, we selectively repudiate and affirm identifications in ways that define us. At some level, a similar exercise was seemingly undertaken by many in our sample.

Continuing on this theme, we noted that several participants not only stated their existential beliefs - they also implicitly disparaged those who held opposing beliefs. Examples of this approach included the two following, non-religious participants:

HKR 215, 70 years: I don't. . .rely on religious beliefs and practices to help me cope with Katrina and Rita. I'm more pragmatic than that.

HKR 308, 91 years: No... I don't [rely on religion]. No, [religious beliefs] did not [help me cope]. I'm mature enough to know [better]. ... .I think I've had enough experience that I can see the thing as it is and live with it. You have to live with it in your own way.

In both of these cases, the participants are not content to simply state their nonreligious stance. They both speak further and offer comments such as "I'm more pragmatic than that" and "I'm mature enough to know [better]"- comments that may be interpreted not only as self-reflection, but also as a jabs at those who invoke religion in their coping and meaning making.

While both of the above comments have an agnostic or atheistic timbre to them, this tendency to implicitly disparage those who saw the world differently was also manifested by some religious persons as well. Two representative statements included:

HKR 206, 73 years: You have faith in God to provide and keep you out of harm's way. If you've got brains enough to listen [to Him]... .

HKR 211, 67 years: [Faith] has a calming effect, and if you are religious, it's ... I don't know, it's a strength that it brings out in you. I feel sorry for people that don't [have it].

As before, in both cases a statement of personal beliefs is followed by implicit condescension of those with contrary beliefs. Two more statements, both from faithbased perspectives, seem to offer additional examples of this point:

HKR 309, 93 years: People who are deeply religious are prone not to worry as much as other people do. Th[ose with faith] say, "Well, we put it into the hands of the Lord. And if it happens, it happens." [Other] people who worry a lot, generally do not live as long as other people do.... I didn't have any fear.

HKR 325, 92 years: [My religion] helps because I know that God can do stuff that we can't do.... The ones that don't believe in God and that have no prayer or don't have nothing at all, I don't know how they [cope] when they get in a tight spot.

Hurricanes Katrina and Rita were, for many, crises. A crisis, as discussed at the outset of this chapter, is a profound developmental challenge or even a turning point. In several of the previous examples, we seem to see persons in crisis who are struggling for their personal existential identities by affirming their own beliefs and repudiating beliefs that are different. Perhaps many of the persons in our study, like 
the elderly Jews studied by the late ethnographer Barbara Myerhoff (1980), "fight [in order] to keep warm" (p. 153).

Most of our South Louisiana sample were at least nominally religious and many were highly so, consistent with research on the high religiosity of the South as a region (Silk \& Walsh, 2006). We now turn to an examination of participants' meaning-making efforts at explaining God's involvement (or lack of involvement) in Katrina and Rita. As mentioned earlier, none of our participants explicitly stated that the hurricanes were divine retribution. However, some participants did state that the disasters were "the Lord's will" or "His plan" without much further explanation. The following five quotes are illustrative:

HKR 16, 43 years: He still performs miracles and $\mathrm{He}$ is still on the throne. It does not matter what is going on in this world today, He is still on the throne...this is just part of His plan.

HKR 207, 89 years: [T] he Lord will give me the protection I need... .And if it's the Lord's will, I can't have anything to worry about... Certain things are out of our hands...

HKR 218, 66 years: [I heard this quote that said], "Your level of stress will go down significantly when you give up your position as general manager of the universe." I just love that! So, I try to remind myself that I am not in control of most of these things... Because I have an abiding trust that things will work out the way the Lord wants them to, and they're not for me to decide. ... I'm just ... Those are things are beyond my control, and I know they're not in my control, so I don't worry about them. I don't.

HKR 104, 60 years: Well, I believe there's a God, and I believe God does everything for a reason. ...So we just got to put our faith in God and go by what He tells us. ... Whatever He throws at us, we got to accept. Lot of times we don't like it, but sometimes we have to accept it.

HKR 206, 73 years: Sometimes (chuckles)... [God's] got His own ideas.

For these participants and many others, the meaning-making effort seemed to be a fairly straightforward affair. Things go "the way the Lord wants them to." They may not understand why, but they accept it, because it is out of their hands anyway.

Others took different approaches in explaining the hurricanes. Some of those approaches involved establishing varying degrees of separation between God and Nature. Some wanted to place some exceptions or limitations on God's control. One said, "I know that God is in control of almost everything that happens. .." Other participants believed that God "puts certain rules on Mother Nature" but that He does not exercise (or choose to exercise) absolute control over Nature. One participant (HKR 13), age 46, explained:

[I] had a lot of my young nieces and nephews ask why... why did God do this? It was the opportunity for me to explain how I've been taught that God...He puts certain rules [on] Mother Nature. . . [but] that this is something that Mother Nature did. [...] He [God] didn't bring it there, it just happened.

For both of the above participants, God is still benevolent and powerful, but perhaps He does not possess or at least exercise all control. The inference from both statements is that there are some bad things that happen, that God does not control. One example of meaning making, from participant, HKR 110 (age 49) seemed to combine elements of divine control with a view of Nature as a separate hostile entity. He said: 
People may not believe it, but God was merciful in where he had Katrina hit because he did move it to the East. If Katrina would've kept going in the path it was headed, [the eye of the hurricane] would've went right over New Orleans then New Orleans would not be there now.

The collection of participants represented above seemed to draw lines of varying thickness between God and Nature, making statements that imply a less than absolute power by God [e.g., that God is in control of "almost everything", that "this is something that Mother Nature did", and that God moved Katrina to the east (but did not obliterate it)]. Unlike the previous group we presented, this group's approaches to meaning making do not insist that the hurricanes were God's will or plan. Further, for some there was passing of hurricane-related blame from God to a (somewhat independent) Mother Nature.

We now turn to another tendency among the interviewed participants. This tendency was not necessarily to identify the causes of the hurricanes, but to offer post hoc explanations rooted in lessons learned. One prevalent explanation was that the hurricanes served as a primer in humility, a reminder that "you're not in control." The following four statements convey this notion:

HKR 115, 51 years: The interesting thing about a hurricane...is there's nothing you can do about it, and for once the world can see that they can't control [things]. This is definitely God. This is a God thing. Not that he is punishing [us] or anything, but it lets you have a perspective of who you really are, that you're not in control. And this is where Katrina [gives us the] right perspective, that God's in control...

HKR 203, 82 years: [Katrina is a reminder that] we need to understand that there always is that power in charge.

HKR 218, 66 years: I [was reminded], you are not in control of the things... . A lot of these things that happen, you're not in control of them.

HKR 101, 62 years: You just have to learn that God can do all things.... We can build walls and house[s] that [we think] the storms can't tear down but when it is time for these things to happen there is nothing we can do.

As indicated above, some participants saw the hurricane experience as a type of divine reminder that we are not in control, while God is. Others emerged with yet another take on the experience.

The last group that will be represented ranged from atheistic to highly religious but shared a central similarity_instead of spending emotional and psychological energy trying to define or explain the hurricanes they had endured, they seemed to strive to make meaning through doing their best in present, at-hand struggles. One highly religious participant (HKR 218) explained:

[I just say], "His will be done." And then [I say], "Give me the strength to handle whatever that will is." ... [My prayer has been], "Your will be done...just give me the strength to handle it."

Participant HKR 9, age 42, also a person of faith, similarly expressed:

I just don't think I could have made it through without knowing that He's there.... [W] hatever happens is going to happen, but He's going to see us through it. 
Another reflection was offered by non-religious participant that seemed to richly capture the sum of meaning making for many of those we interviewed. One participant (HKR 111), age 53, summarized:

Do I think everything happens for the best? No. Do I think we [should try to] make the best out of everything that happens? Yes. That's basically what I believe right there, that we make the best out of what happens.

Despite varying degrees of religiosity and fatalism, these three participants (and many others from our study) shared two central commonalities. First, instead of focusing on the past, they shared a present/future orientation, as illustrated by such statements as "[God is] going to see us through it" and "We [will] make the best out of what happens." The second commonality in their meaning-making perspective is a capabilities-focused paradigm. These are not sheltered and starry-eyed Pollyannas but individuals who have weathered two of the worst natural disasters in Louisiana's history. Still, at the risk of sounding triumphalistic, they manifest an apparent toughness and resilience. What did Katrina "mean"? To many of these participants, it meant (and still means) there is much hard work ahead-work that they will strive to "make the best of."

\section{Discussion}

Each of the three themes discussed in this chapter captures a piece of the participants' collective story of life in the Katrina/Rita aftermath. The first theme (Crisis: Tragedy, Opportunity, or Simply "Part of Life") reflects our participants' experiences of Katrina and Rita as crises in the Eriksonian sense. For some in the sample, the challenges and losses associated with these historic storms made pre-hurricane life as irretrievable as the flooded and now razed homes in the devastated regions of the Gulf Coast. However, these crises were not solely negative. Some individuals reported emerging from the storm with a renewed sense of commitment to "what matters most" and a deeper appreciation for "how precious life is."

The crisis-related analyses in theme 1 offered the most striking cross-cohort finding of our study. Namely, Hurricanes Katrina and Rita were portrayed as crises for most individuals in the two younger (under age 65) cohorts we interviewed, while the hurricanes were typically discussed in more temperate ways by the two senior (over age 65) cohorts. We want to avoid overstating the contrast between the older and the younger cohorts and note that there were one or two individual exceptions (e.g., younger participants who were more stoic). Even so, the overall cohort-based differences were pronounced enough to be identified by all members of the research team. We note that from a historical vantage, the timeframe that separated Cohorts 1 and 2 from 3 and 4 was 1940/1941 - the years immediately preceding the United States' involvement in World War II. Phrased differently, most of Cohorts 1 and 2 were "Baby Boomers," while most members of Cohorts 3 and 4 belonged to what Tom Brokaw (2004) has chronicled as "The Greatest Generation." Whether the relative tendency of the two senior cohorts to minimize the personal influence of HK/R 
is more a function of specific cohort experiences (e.g., the Great Depression and/or World War II years), or whether it is influenced more by age itself, we cannot say. What we can state is that there were cohort differences with respect to whether individuals defined Hurricanes Katrina and Rita as crises or not.

The second theme, "Approaches to Coping," did not reflect cross-cohort differences like theme 1. However, a variety of coping approaches and resources did emerge, including gratitude in the face of loss, optimism as a coping resource, and personal psychological strength. A fourth coping approach, beneficial comparison, was evident as many participants favorably contrasted their situation with persons in worse circumstances. This coping approach meshes with previous research that has found that people "with life-threatening illnesses are likely to compare themselves with those who are in worse shape" (Wood, Taylor, \& Lichtman, 1985; cf. Gilbert, 2006, p. 183) and that $96 \%$ of cancer patients in one classic study selfreported that they were better off than "the average patient" with cancer (Taylor, Falke, Shoptaw, \& Lichtman, 1986). This coping method of selectively focusing on individuals who are worse off, en route to beneficial comparison, might be criticized as pointless self-deception, were it not for the salutary influence of positive reframing and positive perception (Gilbert, 2006). Indeed, a host of symbolic interaction theorists have argued that "perception is reality" and that, as the Thomas Theorem states, "If people define situations as real, they are real in their consequences" (Thomas \& Znaniecki, 1920; cf. LaRossa \& Reitzes, 1993, p. 140). In short, people who see themselves as doing relatively well are more likely to adjust in healthy ways than those who see themselves as failing - as supported by research on the psychology of coping (Pargament, 1997). As a result, in the hurricane aftermath, a critical concern from a psychological perspective is how the affected individuals and families view and define their present situation and their prospective futures. This issue closely relates to the final theme of meaning making.

In connection with meaning making, one of the generally accepted truisms in psychology, family counseling, and human services work is the potency of the "Pygmalion effect" or self-fulfilling prophecy_namely, that our beliefs regarding what will happen to us tend to drive our behaviors in directions that significantly increase the likelihood of the predicted outcome (Corey \& Corey, 2003; Covey, 2004). In light of this point, after the immediate crises have passed, after different coping strategies have been adopted with varying degrees of success, and after meanings have been attributed, it may be that beliefs such as "we make the best out of what happens" will have significant influence in the lives of these survivors. Their individual and collective belief, desire, and effort to prove such "prophecies" true may provide the meaning and thrust necessary to see those visions realized. In conclusion, we come full circle and again hear Frankl's (1984, p. 104) words, "Everything can be taken from a man but one thing: the last of human freedoms-to choose one's attitude in any given set of circumstances, to choose one's own way."

Acknowledgment We thank Tracey Frias, Miranda Melancon, and Zia McWilliams for their assistance with data summary and qualitative analyses. We also thank M.E. Betsy Garrison for her helpful comments on an earlier version of this manuscript. 
This research was supported by grants from the Louisiana Board of Regents through the Millennium Trust Health Excellence Fund [HEF(2001-06)-02] and the National Institute on Aging P01 AG022064. This support is gratefully acknowledged.

\section{References}

Bacher, R., Devlin, T., Calongne, K., Duplechain, J., \& Pertuit, S. (2005). LSU in the eye of the storm: A university model for disaster response. Available at http://www.lsu.edu/pa/book/ EYEofTheSTORMtxt.pdf

Boss, P. (2002). Family stress management. Thousand Oaks, CA: Sage.

Brokaw, T. (2004). The greatest generation. New York: Random House.

Cherry, K. E. (2006, August). Effects of hurricanes Katrina/Rita on the oldest-old. In P. DassBrailsford (Chair), Intersecting dimensions of multicultural issues in disaster response: Aging, disability, ethnicity and SES. Invited symposium presented at the annual meetings of the American Psychological Association, New Orleans, Louisiana.

Cherry, K. E., Allen, P. D., \& Galea, S. (2009). Older adults and natural disasters: Lessons learned from Hurricanes Katrina and Rita. In P. Dass-Brailsford (Ed.), Crisis and disaster counseling: Lessons learned from Hurricane Katrina and other disasters. Thousand Oaks, CA: Sage (in press).

Cherry, K. E., Galea, S., \& Silva, J. L. (2008). Successful aging and natural disasters: Role of adaptation and resiliency in late life. In M. Hersen \& A. M. Gross (Eds.), Handbook of clinical psychology (Vol. 1, pp. 810-833). New Jersey: John Wiley \& Sons, Inc.

Cherry, K. E., Galea, S., Su, L. J., Welsh, D. A., Jazwinski, S. M., Silva, J. L., et al. (2009). Cognitive and psychosocial consequences of Hurricanes Katrina and Rita on middle aged, older, and oldest-old adults in the Louisiana Healthy Aging Study (LHAS) (in press).

Corey, M. S., \& Corey, G. (2003). Becoming a helper (4th ed.). Pacific Grove, CA: Brooks/Cole.

Covey, S. R. (2004). The 7 habits of highly effective people. New York: Free Press.

Erikson, E. H. (1998). The life cycle completed. New York: Norton.

Erikson, J. M. (1998). Gerotranscendence. In E. H. Erikson (Ed.), The life cycle completed (pp. 123-129). New York: Norton.

Fosdick, H. E. (1918). The meaning of faith. New York: Association Press.

Frankl, V. (1984). Man's search for meaning. New York: Washington Street Press.

Garrison, M. E., Malia, J. A., \& Molgaard, V. K. (1991). Conceptual and theoretical integration of family resource management theory and family stress theory. Themis: Journal of Theory in Home Economics, 1, 1-17.

Gilbert, D. (2006). Stumbling on happiness. New York: Vintage.

Hill, R. (1949). Families under stress: Adjustment to the crisis of war separation and reunion. New York: Harper and Brothers.

Ingoldsby, B., Smith, S., \& Miller, J. E. (2004). Exploring family theories. New York: Roxbury.

Koos, E. L. (1946). Families in trouble. New York: Kings Crown Press.

LaRossa, R., \& Reitzes, D. C. (1993). Symbolic interactionism and family studies. In P. G. Boss, W. J. Doherty, R. LaRossa, W. R. Schumm, \& S. K. Steinmetz (Eds.), Sourcebook of family theories and methods: A contextual approach (pp. 135-163). New York: Plenum Press.

Marks, L. D. (2002). Illuminating the interface between families and face. Unpublished doctoral dissertation, University of Delaware, Newark.

Marks, L. D., Nesteruk, O., Swanson, M., Garrison, M. E. B., \& Davis, T. (2005). Religion and health among African Americans: A qualitative examination. Research on Aging, 27, $447-474$.

Marks, L. D., Swanson, M., Nesteruk, O., \& Hopkins-Williams, K. (2006). Stressors in African American marriages and families: A qualitative study. Stress, Trauma, and Crisis: An International Journal, 9, 203-225. 
Menaghan, E. G. (1983). Individual coping efforts: Moderators of the relationship between life stress and mental health outcomes. In H. B. Kaplan (Ed.), Psychosocial stress: Trends in theory and research (pp. 157-192). New York: Academic Press.

Miles, M. B., \& Huberman, A. M. (1994). Qualitative data analysis: An expanded sourcebook. Thousand Oaks, CA: Sage.

Myerhoff, B. (1980). Number our days. New York: Touchstone.

Nesteruk, O., \& Garrison, M. E. B. (2005). An exploratory study of the relationship between family daily hassles and family coping and managing strategies. Family and Consumer Sciences Research Journal, 34, 140-152.

Pargament, K. I. (1997). The psychology of religion and coping: Theory, research, and practice. New York: Guilford.

Patton, M. Q. (2002). Qualitative research \& evaluation methods (3rd ed.). Thousand Oaks, CA: Sage.

Rose, C. (2007). 1 dead in attic: After Katrina. New York: Simon \& Schuster.

Seligman, M. E. P. (2004). Authentic happiness: Using the new positive psychology to realize your potential for lasting fulfillment. New York: Free Press.

Seligman, M. E. P., \& Csikszentmihalyi, M. (2000). Positive psychology: An introduction. American Psychologist, 55, 5-14.

Silk, M., \& Walsh, A. (2006). Religion by region: Religion and public life in the United States. Blue Ridge Summit, PA: AltaMira.

Strauss, A., \& Corbin, J. (1998). Basics of qualitative research: Techniques and procedures for developing grounded theory. Thousand Oaks, CA: Sage.

Taylor, S. E., Falke, R. L., Shoptaw, S. J., \& Lichtman, R. R. (1986). Social support, support groups, and the cancer patient. Journal of Consulting and Clinical Psychology, 54, 608-615.

Thomas, W. I., \& Zaniecki, F. (1920). The Polish peasant in Europe and America. Boston, MA: Badger.

Webster's New World Dictionary. (1991, 3rd ed.). New York: Simon \& Schuster.

Wood, J. V., Taylor, S. E., \& Lichtman (1985). Social comparison and adjustment to breast cancer. Journal of Personality and Social Psychology, 49, 1169-1183. 